\title{
Human Capital as a Factor of the Intensive Development of the Company
}

\author{
Zhdanov D.A. \\ Central Economics and Mathematics Institute, RAS, \\ Moscow, Russia, \\ djhdanov@mail.ru
}

\author{
Mikirtichan A.G. \\ Moscow Technical University \\ of Communication and Informatics, \\ Moscow, Russia, \\ 7844471@gmail.com
}

\begin{abstract}
One of the key factors determining the company's success, ensuring its progressive development and adaptation to the requirements of the digital economy, is the company's human capital (HC). In this regard, the purpose of the study is to identify ways to support the company's holistic and sustainable growth based on the development of its HC. Since the company is an open socio-economic system, the methodological basis of the article was the system economic theory, which allowed us to present the company's activities as an interaction of object, environment, process and project systems. Based on this concept and taking into account the tasks traditionally solved by the company, four basic functional complexes of the enterprise that ensure its stability and reproduction capabilities are identified, as well as problems implemented within them, and requirements for the knowledge, skills and abilities of personnel are established. Comparison of human resources of the enterprise and corporate tasks, solved with their help, made it possible to group the elements of the company's $\mathrm{HC}$ in a new way, depending on the impact on the basic complexes that determine the company integrity. The systematization demonstrated the relationship between individual elements of the enterprise's $\mathrm{HC}$ and the performance of the corresponding complexes. Thus, the probable personnel reasons for the lag in certain areas of the company's activities and the possibility of their rehabilitation by targeting the desired elements of the $\mathrm{HC}$ are determined.
\end{abstract}

Keywords—systems economics, corporate and individual human capital

\section{INTRODUCTION}

The company's competitiveness largely depends on its unique advantages and key competencies. Such a valuable, rare and difficult to copy resource is the enterprise human capital, which determines the possibilities of its intensive development. The task of forming and rational use of the HC, increasing its potential, which is especially in demand in the digital economy, is acute for Russian companies. This is due, in particular, to a decrease in the demographic indicators of the working population, as well as to the low quality of higher and special education. At the same time, these circumstances reduce the competitiveness of the entire economy and slow down its development.

\section{Purpose OF THE STUdY}

Responses to these challenges are associated with the study of the mechanisms of functioning and ways to increase the enterprise's $\mathrm{HC}$ and its impact on the performance of national producers. In this regard, the purpose of this study was to identify ways to ensure a holistic and sustainable growth of the company based on the development of its $\mathrm{HC}$.

In the work of the research applied the following logic. On the one hand, the task is to position the enterprise within the framework of system economic theory and consider the subsystems that ensure the integrity of the company's functioning. On the other hand, it is necessary to analyze the elements that form the enterprise's HC, which determine both its potential and the direction of impact. Based on the results obtained, it is planned to install the components of the HC that determine the full functioning of the selected subsystems of the company and, finally, to demonstrate the practical application of the results obtained.

\section{RESEARCH METHOD}

Since the HC affects various aspects of the enterprise's activity, the totality of its production, economic and social tasks, the study uses the system economic theory as the main methodological approach, which determines the paradigm of economic knowledge integration. It refers to the concept of system stability of the economy and allows us to present the production system as an integral part of the world, relatively stable in time and space.

\section{THE ATTRIBUTES OF THE ENTERPRISE SYSNEM IN LINE WITH ECONOMIC THEORY}

As it is mentioned in the introduction, the methodological basis of the article was the system economic theory [1-4]. In this regard, we summarize its main theses that are relevant for this study.

In accordance with this concept, the activity of any economic entity is considered as the functioning of a system 
endowed with a universal fundamental structure consisting of four elements (subsystems) that differ from each other by the presence of boundaries in space (spatial localization) and (or) in time (temporal localization). In this case, the fundamental typology of economic systems at the top level of classification includes the following basic types, which differ in their spatial and temporal characteristics [5]:

- objects (object systems) - limited in space and not limited in time of the system's existence;

- environments (environmental systems) - not limited either in time or in space;

- $\quad$ processes (process systems) - systems that do not have a priori territorial (spatial) restrictions and are limited in time;

- projects or events (project systems) - limited in both spatial and temporal senses of the system.

A prerequisite for the sustainable functioning of an economic entity, such as a region, industry, or enterprise, is the balance of its internal system structure, that is, the presence of a complex of subsystems of object, environment, process, and project types, reflecting, respectively, the role of organizational and managerial, social, technical, economic, and entrepreneurial factors. The full functioning of such an entity requires coordination of the interests of groups representing the listed factors and consolidation of its subsystems.

The enterprise, as a socio-economic system, is characterized by the presence of a set of immanent subsystems that ensure the stability and reproduction cycle of the company [5]. At the same time, it is important that the subsystems are provided with sufficient resources for balanced functioning. In line with the concept under consideration, the basic system structure of any enterprise is a four-element configuration, which includes the following identification components corresponding to the noted factors:

- the administrative sphere - the enterprise management (it represents the object system);

- social sphere - interaction of enterprise employees (reflects the environmental system);

- technical and economic area - implementation of production and economic processes (represents the process system);

- business sphere - implementation of investment projects (corresponds to the project system).

Or, if we detail these four subsystems in line with the tasks traditionally implemented by the company, you can identify the following complexes that are responsible for the identity and integrity of the company:

- institutional and organizational complex - the enterprise management, administrative and managerial interaction, regulations that determine the relations of participants;

- social and labor complex - the labor collective of the enterprise, social relations in divisions;
- property and technology complex - a set of the enterprise assets, as well as production, reproduction, distribution and exchange processes;

- business model complex - the projects of the enterprise development, other investment programs.

Adhering to the system view adopted in the article, it is possible to identify a person from four angles, taking into account their localization in space and time. On the one hand, it acts as a subject that supports its reproductive potential, on the other - as a citizen who interacts with other people and society as a whole, on the third - as an employee who performs production and distribution operations, on the fourth - as an entrepreneur who initiates new projects. These characteristics correspond to the marked four-component typology of economic systems: object-environment-processproject. In this case, a company employee is a structural element located at the "nanoscale" of the system vertical.

\section{HUMAN CAPITAL AS A RESOURCE FOR ENTERPRISE DEVELOPMENT}

We will now discuss the second aspect of the study-the properties of the $\mathrm{HC}$ as a factor that significantly determines the company's activities. The formation of the concept of $\mathrm{HC}$ is connected with the desire to explain the role of intangible and inseparable assets in the creation of a social product, by analogy of material resources. There is still a discussion about what characteristics are rightfully attributed to the $\mathrm{HC}$ - only knowledge, skills and competencies used by a person in production processes, or also a set of social, psychological, ideological and cultural characteristics of the individual? Can the whole combination of acquired and natural properties and abilities be considered human capital, or only those that can bring returns?

In this paper, we will adhere to an expanded interpretation of the $\mathrm{HC}$, including in its composition also a set of personal qualities, social competencies, and value orientations that can influence the effectiveness of productive activities. This position is most closely reflected in the following definition adopted in this work: "Human capital is the knowledge, competencies and characteristics embodied in individuals that contribute to the creation of personal, social and economic well-being" [6].

In turn, the term corporate $\mathrm{HC}$ will be used to refer to the total HC of the company's employees, used to achieve the goals of the organization, bringing it a return. Moreover, the corporate $\mathrm{HC}$ should not be considered only as the sum of employees' HC (their knowledge, experience, behavior, attitude to the company and colleagues). First, there is an additional synergy from the joint use of individual abilities, and secondly, the company, as an economic entity, requires and forms its own qualities that ensure its sustainable functioning and development, for example, corporate culture, intellectual property, relations with partners of the company. Their carrier is the collective HC of the company.

The corporate $\mathrm{HC}$, for its part, also affects the individual capital of the employee. This influence is carried out by strengthening existing and forming missing components, so by 
mastering new equipment, completing production tasks, employees improve their work skills, acquire professional competencies, and expand their social and intellectual abilities.

Speaking about the place of the $\mathrm{HC}$ in a number of other factors of production, it should be noted its key importance. HC significantly determines the success or failure of the company. An enterprise may have buildings and equipment, but they will not work until a person starts using them in their activities, and the more efficiently they use them, the greater the return the company will receive. This is clearly seen in the development and implementation of innovations that are the basis of the competitive advantages of a modern company. They are carried out precisely because of the creative abilities of employees, so successful companies create structures, processes and motivation that promote the emergence of new ideas.

Let's consider initially the human capital of individual employees who form the collective capital of the enterprise. The elements that make up individual capital, taking into account their interpretation options, are grouped into the following categories:

- educational capital (a set of knowledge and skills);

- health capital (health analysis and support);

- social and psychological capital (psychological stability, strong-willed qualities, ability to establish relationships with other people and social institutions, to socially useful activities);

- cultural and moral capital (mentality, upbringing, ethics, empathy),

- professional capital (qualifications, general and special skills, experience);

- intellectual and creative capital (creativity, ability to research, invent, rationalize, solve new problems);

- organizational capital (ability to work creatively, motivation for economic activity, ability to achieve results, responsibility, initiative);

- entrepreneurial capital (ability to set goals, think outside the box, innovate, focus on finding innovative approaches, and take reasonable risks).

If we compare the four "hypostases" of human activity highlighted in the previous section, as an element of the system vertical, and the components that form its capital, we can determine their mutual correspondence, which allows us to group the elements of an individual $\mathrm{HC}$ in a new way, taking into account their system positioning, and assess the value for the development of the potential of employees. The proposed distribution is demonstrated in Table I.

As you can see, the success of the employee each of the four sides of activities is determined by the set component of the HC, so staff recruitment should be conducted, given the presence of the candidates abilities required for the vacant positions, or the possibility of their formation, which in particular allows to determine targets for additional training.
TABLE I. COMPLIANCE OF THE COMPANY EMPLOYEE'S ACTIVITY CERTAIN ASPECTS WITH THE COMPONENTS OF INDIVIDUAL HUMAN CAPITAL

\begin{tabular}{|l|l|}
\hline $\begin{array}{c}\text { Components of an } \\
\text { employee's activity }\end{array}$ & \multicolumn{1}{c|}{ Individual human capital components } \\
\hline "Subject" & Object: education and health capital \\
\hline "Citizen" & $\begin{array}{l}\text { Environmental: social, psychological, cultural } \\
\text { and moral capital }\end{array}$ \\
\hline "Employee" & $\begin{array}{l}\text { Process: professional, intellectual, creative and } \\
\text { organizational capital }\end{array}$ \\
\hline "Entrepreneur" & Project: entrepreneur's capital \\
\hline
\end{tabular}

Source: author

Let us now consider the impact of the $\mathrm{HC}$ on the functioning of the four previously identified subsystems of the company. In this regard, the question is what functional tasks are solved within each of them? The answer to it, on the one hand, allows us to see the place of the marked complexes in the system of tasks solved by the company, and on the other, to determine the requirements for the personnel potential of the enterprise. It is the need to resolve existing production problems that determines the requirements for the experience, knowledge, competencies and personal qualities of the organization's employees. As a result, we highlight the following tasks that can be solved in these areas:

- institutional and organizational complex implementation of administrative and managerial actions aimed at achieving business goals, establishing relationships between divisions and subsystems of the enterprise, quality control, monitoring of labor resources, etc.;

- social and labor complex - establishing social interaction between members of the labor collective, maintaining an adequate corporate culture, establishing a psychological climate in the team;

- property and technology complex - ensuring the implementation of the necessary production and reproduction processes, conducting commercial activities;

- business model complex - preparation and implementation of projects for enterprise development, innovation, modernization of the social sphere, entering new markets, and rationalization of relationships with partners.

So, having noted the tasks facing the company, we will evaluate what knowledge, skills, and abilities are necessary to solve them. In this connection, we will consider the composition and content of the elements that form the enterprise's HC.

There are various approaches to its systematization in the literature. Thus, the company's human capital, along with organizational (structural) ${ }^{1}$, social $^{2}$ and consumer (relational)capital, appears as a component of intellectual capital (knowledge accumulated by the company), as a non-

1 According to [7], organizational capital is the assimilated knowledge that an organization has its internal processes and procedures. This capital is sometimes referred to as structural capital [8]

${ }^{2}$ Social capital is defined as "the totality of knowledge gained through a network of relationships both inside and outside the organization" [9]. 
physical resource for creating added value [9-11]. However, since the content of organizational, social and consumer capital is the product of applying the totality of knowledge, skills and abilities of employees, we will consider such capital according to [12] as manifestations of corporate HC. In other works, for example, in [13], attention is drawn to the institutional components of the corporate HC. The transformation of the enterprise's $\mathrm{HC}$ in the digital economy and changes in its content within Industry 4.0 are reflected in [14-16].

As a result we will highlight the following positions that form the corporate $\mathrm{HC}$ :

- structural (organizational) capital is a manifestation of the organizational potential of the company in the form of a management system, technology, organizational structure, the total mentality of the staff and internal relationships;

- social capital characterizes interpersonal interactions in an organization, expressed in social connections, shared values, norms, trust, and responsibility;

- production capital covers a set of methods for solving problems, knowledge, skills, and abilities of employees used by them to conduct production activities;

- relational capital (market, partner), represents the organization's system of relations with partners, business reputation, and the practice of resolving external conflicts;

- innovative and intellectual capital includes knowledge and competencies necessary for future success, intellectual assets, patents, know-how, and licenses.

Earlier, speaking about the four enterprise subsystems, we described the tasks to be solved within each of them, and now we will focus on the required funds. Comparing the tasks facing the enterprise and the available human resources, we will highlight the elements of the $\mathrm{HC}$ designed to solve the noted problems of business development. As a result, it is possible to combine the designated elements of the corporate $\mathrm{HC}$ into four categories that differ in the degree of influence on the basic subsystems that ensure the integrity of the enterprise. Let's call these components that meet the corresponding needs of the enterprise: object, environment, process, project, which reflects their spatial and temporal localization. The results of this projection are shown in Table II.

TABLE II. CORRESPONDENCE OF THE ELEMENTS THAT MAKE UP THE CORPORATE HUMAN CAPITAL TO THE STUDIED ENTERPRISE SUBSYSTEMS

\begin{tabular}{|l|l|}
\hline \multicolumn{1}{|c|}{ Enterprise subsystems } & \multicolumn{1}{c|}{$\begin{array}{c}\text { Corporate human capital } \\
\text { components }\end{array}$} \\
\hline Institutional and organizational & Object: structural capital \\
\hline Social and labor & Environmental: social capital \\
\hline Property and technology & $\begin{array}{l}\text { Process: production and relational } \\
\text { capital }\end{array}$ \\
\hline Business model & $\begin{array}{l}\text { Project: innovative and intellectual } \\
\text { capital }\end{array}$ \\
\hline
\end{tabular}

Since the implementation of the tasks solved within each of the subsystems is carried out to a significant extent with the help of the corresponding $\mathrm{HC}$ elements, it is their impact that ensures the successful maintenance of a balanced enterprise internal structure and its progressive growth.

The noted relationships are demonstrated in Fig. 1, which reflects the impact of the components of the corporate $\mathrm{HC}$ on the enterprise subsystems.

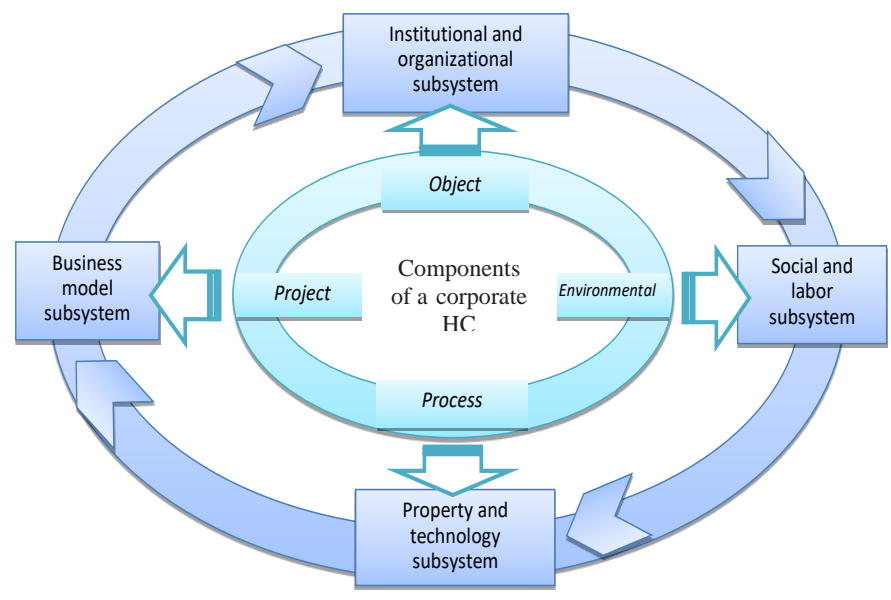

Source:author

Fig. 1. Priority directions of corporate human capital elements impact on enterprise subsystems

Let us pay attention to the fact that according to the system paradigm that this study follows, the prerequisite for a company's sustainable development is the consistency of its four identification subsystems. If some of them lag behind (which threatens the integrity of the company), it is necessary to determine the reasons for the mismatch and measures to activate them. Such a tool is actions to activate the relevant elements of the corporate HC.

\section{PRACTICE IN THE APPLICATION}

In conclusion, we will illustrate the use of this approach using a practical situation. In the company $\mathrm{N}$, whose activities the author studied, there were problems with internal communications, the management noted poor horizontal interaction of employees, which affected the quality and timing of work, that is, in terms of this article, the social and labor subsystem did not function actively enough. The success of its work, according to the introduced approach, is determined by the elements of the corporate $\mathrm{HC}$, combined within the framework of social capital.

In this regard, the assessment of the relevant components of the HC was carried out, which showed the probable cause the lack of such interpersonal components as trust and coordination of actions of employees of interrelated, but functionally separate divisions. To remedy the situation, it was decided to implement measures aimed at strengthening the mentioned elements. These include the following actions related to employee development and positioning:

- introduction of KPIs that take into account cross-group results and bonuses for their achievement; 
- establishing an inter-group discussion on the implementation of decisions (regular meetings involving employees of various services);

- conducting trainings on team building;

- temporary relocation of employees to a related division.

The combination of actions carried out allowed, in the end, to restore the situation to the healthy state.

\section{CONCLUSION}

The effectiveness of companies in the context of the growing role of innovation and digitalization significantly depends on the level of development of the corporate human capital (HC), which is a determining resource for intensive growth. In this regard, we studied the possibilities of improving the operation of the enterprise with the help of its HC.

Based on the analysis of the characteristics of economic actors, ensuring their stability and reproductive capacity allocated four basic functional complexes of the company, the tasks within each, and established requirements for knowledge, skills and abilities of staff. A similar system view is applied to the analysis of the employee's activity as an economic entity located at the nanoscale of the system vertical. As a result, four basic components of its activity are recorded. Their correlation with the elements that form an individual human capital made it possible to combine the latter in terms of the degree of influence on the key aspects of human activity, to determine the priority areas of employee training.

Comparison of the company's human resources (characterized by indicators that determine the company's HC), on the one hand, and corporate tasks solved with their help, on the other, allowed us to group the elements of the company's $\mathrm{HC}$ in a new way, depending on the impact on the four basic complexes that ensure the integrity of the company. On the basis of systematization of we have generated rehabilitation range of tools for the certain enterprise facilities, in case of delayed or abnormal (asynchronous) enterprise activity, based on the activation of corporate $\mathrm{HC}$ relevant elements.

\section{Acknowledgment}

The article is funded by the Russian Foundation for Basic Research within the framework of the scientific project № 1929-07488.

\section{References}

[1] J. Kornai, "System paradigm" ["Sistemnaya paradigma"], The Question of its Economy [Voprosy` e'konomiki], 2002, vol. 5, pp. 4-22. (In Russ.).

[2] G.B. Klejner, "The new theory of economic systems and its applications" [Novaya teoriya ekonomicheskikh sistem i ee prilozheniya], Journal of Economic Theories [Zhurnal e`konomicheskoj teorii], 2010, vol. 3, pp. 41-58. (In Russ.).

[3] V.L. Makarov and A.R. Baxtizin, "Social modeling is a new computer breakthrough. Agent Oriented Models" ["Sotsial'noe modelirovanie novyy komp'yuternyy proryv. Agent-orientirovannye modeli”], Moscow, 2013. (In Russ.).

[4] G. B. Klejner and M.A. Ry`bachuk, "Systemic Economic Balance" ["Sistemnaya sbalansirovannost' ekonomiki"], Moscow, 2017. (In Russ.).

[5] G.B. Klejner, "Systemic modernization of domestic enterprises: theoretical justification, motives, principles" ["Sistemnaya modernizatsiya otechestvennykh predpriyatiy: teoreticheskoe obosnovanie, motivy, printsipy"], Regional Economy [Ekonomika regiona], 2017, vol. 13(1), pp. 13-24. (In Russ.).

[6] OECD, "The Well-being of nations: The role of human and social capital", Paris: OECD, 2001.

[7] M.A. Youndt, "Human resource configurations and value creation: The mediating role of intellectual capital". Annual Conference of the Academy of Management, Toronto, 2000.

[8] L. Edvinsson and M.S. Mallone, "Intellectual Capital: Realizing Your Company's True Value by Finding its Hidden Brain Power, Harper Business", N.Y. P., 2007.

[9] M. Armstrong, "Human Resource Management Practice" ["Praktika upravleniya chelovecheskimi resursami”]. SPb.: Piter, 2012. (In Russ.).

[10] A.G. Magradze, "Human capital as an element of intellectual capital: existing indices and methods for measuring it and the impact on the capitalization of domestic companies" ["Chelovecheskiy kapital kak element intellektual'nogo kapitala: sushchestvuyushchie indeksy i metody ego izmereniya i vliyanie na kapitalizatsiyu otechestvennykh kompaniy"], Fundamental Research [Fundamental`ny`e issledovaniya], 2019, vol. 12(1), pp. 224-232. (In Russ.).

[11] S. Samad, "Achieving innovative firm performance through human capital and the effect of social capital", Management and Marketing, 2020, vol. 15(2), pp. 326-344.

[12] L. Gratton and S. Ghoshal, "Managing personal human capital: new ethos for the 'volunteer' employee", European Management Journal, 2003, vol. 21(1), pp. 1-10.

[13] A.I. Borodin, N.N. Shash and A. Sorochajkin, "Company Human Capital: Identification Issues" ["Chelovecheskiy kapital kompanii: problemy identifikatsii”], Fundamentals of Economics, Management and Law [Osnovy ekonomiki, upravleniya i prava], 2013, vol. 4(10), pp. 103-109. (In Russ.).

[14] E. Zainutdinova and G. Khaziakhmetova, "Retrospective study of approaches to the definition of «human capital»", Journal of Advanced Research in Dynamical and Control Systems, 2019, vol. 11(8), pp. 1806 1809 .

[15] I.A. Ivanova, A.M. Odinaev, V.N. Pulyaeva, A.A. Gibadullin and A.V. Vlasov, "The transformation of human capital during the transition to a digital environment", Journal of Physics: Conference Series, 2020. (In Russ.). DOI: htpps://doi.org/10.1088/1742-6596/1515/3/032024

[16] E. Flores, X. Xu and Y. Lu, "Human Capital 4.0: a workforce competence typology for Industry 4.0", Journal of Manufacturing Technology Management, 2020, vol. 31(4), pp. 687-70. 